\title{
Seasonally dry tropical forest temporal patterns are marked by floristic stability and structural changes
}

Cléber Rodrigo de Souza 1iD, Alisson Borges Miranda Santos ${ }^{1 \mathrm{iD}}$, Vinícius Andrade Maia1, Gabriela Gomes Pires de Paula ${ }^{1}$, Nathalle Cristine Alencar Fagundes ${ }^{1}$, Polyanne Aparecida Coelho ${ }^{1 \mathrm{iD}}$, Paola Ferreira Santos ${ }^{1 \mathrm{iD}}$, Jean Daniel Morel ${ }^{1 \mathrm{iD}}$, Paulo Oswaldo Garcia1, Rubens Manoel dos Santos ${ }^{1 i D}$

${ }^{1}$ Federal University of Lavras, Lavras, Minas Gerais, Brazil

FOREST ECOLOGY

\section{ABSTRACT}

Background: Seasonally Dry Tropical Forests (SDTF) are recognized by their great biological diversity, but little is known about their temporal patterns, which may be crucial in a changing world. Here we aimed to characterize the SDTF dynamic patterns in floristic and structural changes, and also to evaluate shifts in dynamic rates and structural attributes such as richness, number of trees and biomass. Our hypothesis is that SDTF tree communities have their dynamic characterized by temporal fluctuations related to an instability pattern, in according to the already found for others tropical forests. For this we used a data of $42400 \mathrm{~m}^{2}$ plots in three fragments in the Brazilian Arboreal Caatinga, measured in 2005, 2010 and 2015. We evaluated temporal changes in richness, species composition, trees density, biomass and rates of tree mortality and recruitment; and also rates of biomass gain and loss.

Results: We found a pattern of floristic composition stability, but with changes in structure and dynamics. There was a tree density decrease driven by constant mortality and by recruitment decrease, and biomass increase due to decrease in biomass loss and to increase in biomass gain. The biomass increase was main related to a small set of dominant species that are the most representative in the community dynamics.

Conclusion: SDTF dynamics are related to stability in species composition, but with structural changes towards higher biomass stocks. The results are main related to community dynamics and to SDTF attributes such as climatic seasonality that drives the local ecological processes.

Keywords: Biomass increase; Caatinga Domain; communities stability; ecological dominance

\section{HIGHLIGHTS}

Seasonally dry tropical forests dynamic is marked by relative stability and tree increase. Local temporal changes occurred towards trees density decrease and biomass increase. Tree communities in tropical dry forests were not related to short-time floristic changes. The biomass increase occurred by indicator species due to its competitive advantage.

SOUZA, C. R.; SANTOS, A. B. M.; MAIA, V.A.; PAULA, G. G. P.; FAGUNDES, N. C. A; COELHO, P. A.; SANTOS, P, F.; MOREL, J. D.; GARCIA, P. O.; SANTOS, R. M. Seasonally dry tropical forest temporal patterns are marked by floristic stability and structural changes. CERNE, v. 27, e-102355, doi: 10.1590/01047760202127012355 


\section{INTRODUCTION}

Tropical forests are dynamic systems that present continuous variations at both species population and individual levels throughout space and time (Roitman et al., 2016; McDowell et al., 2020). These ecological processes may be related to environmental conditions and resource availability or/and to stochasticity and unpredictable events, in which different ecosystems present different specific importance of each one (Cadotte and Tucker, 2017; McDowell et al., 2020). In seasonally dry tropical forests (SDTF) ecosystems, the tree communities' ecological patterns are broad related to climatic seasonality (DRYFLOR, 2016; Pennington et al., 2018; Maia et al., 2020). These vegetation types occur at sites with annual mean rainfall less than $1,800 \mathrm{~mm}$ and in which three or more months receive less than $100 \mathrm{~mm}$, with approximately 80 $90 \%$ of the annual precipitation distributed irregularly and unpredictably within the rainy season (DRYFLOR, 2016; Pennington et al., 2018).

Due to its great climatic seasonality, ecological processes of growth and recruitment of tree individuals in SDTF occur predominant during the rainy season or after erratic rains occurring in the dry season, when more resources are available and the chance of establishment increases (Pennington et al., 2009; Maestre et al., 2016; Allen et al., 2017). However, variations in climatic variables such as rainfall amount and temperature may occur between years and thus induce changes in ecological processes and consequently in the tree communities demographic rates and biomass (Toledo et al., 2011; Niu et al., 2014; Allen et al., 2017; McDowell et al., 2020).

These variations can also occur as changes in the timing of wet or dry seasons that may influence the stability of SDTF tree communities, since structured ecological patterns and process are affected (Maestre et al., 2016; Allen et al., 2017). The tree communities stability has been defined as the absence of large temporal fluctuations in attributes such as floristic composition, diversity (species richness and equability), demographic patterns and total biomass (Lehman and Tilman, 2000; Donohue et al., 2016; McDowell et al., 2020). Such fluctuations are naturally expected in ecological communities and are commonly responses to natural factors, such as climatic seasonality, and or/also to anthropic disturbances that may destabilize it and determine the forest successional dynamics and its structural development (Lewis et al., 2009; Swanson et al., 2011; Donohue et al., 2016; Swenson et al., 2020).

These tree community temporal changes in trees density, biomass, richness and floristic composition, should be considered differently across the temporal scales (Donohue et al., 2016; McDowell et al., 2020). Thus, while changes in structural variables such as density and biomass can be observed in short time-scale (Phillips and Lewis, 2014; Prado-Junior et al., 2016), changes in composition are more subtle (Esquivel-Muelbert et al., 2017; Feeley et al., 2020). In this context the long-term monitoring of communities is a main issue for scientific efforts, since allows to understand the complexity of ecological processes, to evaluate the tree communities stability, and also to design future scenarios for the ecosystems functioning (Bello et al., 2020; McDowell et al., 2020).

However, there is still a lack of investigations about temporal changes of seasonally dry tropical forests functionality. These forests have historically received less attention from the scientific community (Pennington et al., 2009; Sunderland et al., 2015), and the most studies are focused on the floristic and structural characterization in a space approach (Albuquerque et al., 2012; DRYFLOR, 2016; Souza et al., 2019; Maia et al., 2020). Therefore, studies that analyze the tree communities dynamic in SDTF are scarce (Albuquerque et al., 2012; Reis et al., 2017), instead of other vegetation types such as the Rain Forests that have been had monitoring for decades (Lewis et al., 2009; Phillips and Lewis, 2014; Brienen et al., 2015; Meyer et al., 2015; Roitman et al., 2016; Santos et al., 2018; Sullivan et al., 2020).

Thus, here we aimed to characterize the seasonally dry tropical forests temporal patterns by monitoring three fragments (42 plots) for 10 years. For this we evaluated whether the tree community attributes of individuals density, biomass, species richness and floristic composition varied throughout the evaluated period. We start from the hypothesis that the SDTF tree communities present its dynamic patterns characterized by temporal fluctuations that configure an instability pattern, since these patterns have been observed for other tropical forests.

\section{MATERIAL AND METHODS}

\section{Study area}

The studied areas are three fragments of seasonally dry tropical forest located in the southern limit of the Brazilian Caatinga domain, in Juvenília (14²6 $04^{\prime \prime} \mathrm{S}$; 44010'67"W), north of the Minas Gerais state, Brazil (Fig. 1). The climate in the region is classified as Köppen Aw/As (tropical dry winter) with average temperature of $24.6{ }^{\circ} \mathrm{C}$ and average annual rainfall of $868 \mathrm{~mm}$, distributed in two contrasting periods (Santos et al., 2012). The relief is flat in the three fragments and the altitude average is 450 $\mathrm{m}$. The landscape is characterized by degraded pastures and abandoned areas in initial stage of regeneration. The vegetation in the studied fragments are classified as Arboreal Caatinga, characterized as a forest type of up to $20 \mathrm{~m}$ where most of the species are deciduous during the dry season (Santos et al., 2012). This issue was addressed in Santos et al. (2012), in which this vegetation type was recognized as the arboreal expression of the Caatinga Domain flora.

\section{Data collection}

We made three forest inventories in the fragments in 2005, 2010 and 2015. In 2005, we systematically allocate 42 sampling units of $400 \mathrm{~m}^{2}$ (20x20m) distributed among the fragments, 20 in fragment 1 (Vale Verde), 12 in fragment 2 (Lapinha) and 10 in fragment 3 (Poço da Jia). Within each sample unit we measured and identified at the 


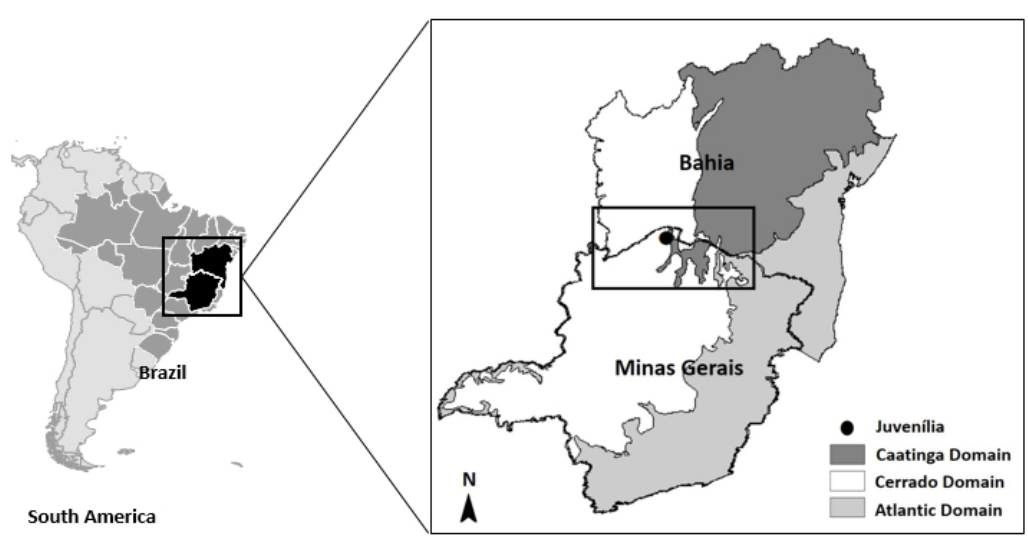

Fig. 1 Location of study areas (Juvenilia) in the state of Minas Gerais, Brazil and South America, and in relation to the Brazilian phytogeographic domains. species level all arboreal individuals with circumference at breast height $(\mathrm{CBH}) \geq 10 \mathrm{~cm}$. Individuals with more than one stem were included when the sum of squares root of their circumferences reached the inclusion criterion. The botanical identification followed the APG IV (ANGIOSPERM PHYLOGENY GROUP - APG, 2016) and was carried out in the field by specialists. In the following forest inventories (2010 and 2015), all individuals found in previous inventories were measured again, in addition to measure the individuals who met the criterion (recruits) and count the dead individuals in the period between measurements.

\section{Data analysis}

Initially we evaluated whether the density (tree. $\mathrm{ha}^{-1}$ ), biomass (ton/ha), biomass per individual (ton) and species richness varied significantly between the years of measurement. To test it we used generalized linear generalized models (GLMM), using each of the attributes cited as response variable, the years of measurement as a fixed explanatory variable. Next, we evaluated the communities' temporal trend for tree mortality and recruitment; biomass gain and loss; and in relation to temporal species substitution. For this, we calculated the annual rates of Mortality (M) and Recruitment (R) of individuals, Gain $(G)$ and Loss (P) of biomass (Sheil et al., 2000) and temporal beta diversity for the intervals between inventories (2005-2010 and 2010-2015). Here we also used GLMM with the dynamic variables as response variable and the interval of measurement as explanatory variable.

For all analysis, we used "plot" and "fragment" as random factors to deal with the repeated measures at the same plot and the fragments, in order to control the spatial autocorrelation found in models residuals. For density and richness, we used the Poisson family with "log" link function, while for the other variables we used the Gaussian family and the "identity" link function. When necessary, we performed transformations on the response variables in order to achieve the variance homogeneity and residuals normality. All selected models were absent of spatial autocorrelation.

The biomass values were obtained for each tree using the Pantropical equation of Chave et al. (2014), through the Biomass package (Rejou-Mechaine et al., 2017), that is broadly used to obtain the above-ground biomass (AGB) using data of diameter, species wood density and an $E$ measure of restrictiveness. All analyzes were performed in the R Studio version 3.3.1 program, using the packages vegan, betapart, Ime4, MuMin, ImerTest and ncf.

\section{RESULTS}

The Seasonally Dry Tropical Forest communities were floristically stable, but with significant temporal changes in structure and dynamics. Tree density (ind.ha- ${ }^{-1}$ ) decreased significantly from 1,606.5 trees.ha- ${ }^{-1}$ in 2005 to 1,480.4 trees. ha-1 in 2015 (est=-0.03; $p=0.0028$ ) (Fig. 2a), while the total biomass increased significantly from 104.5 ton.ha-1 in 2005 to 122.1 ton. ha $^{-1}$ in 2015 (est=0.07; p<0.01) (Fig. 2a) and the biomass per tree increased significantly from 0.065 ton in 2005 to 0.082 ton in 2015 (est=0.02; $p<0.01$ ) (Fig. 2b). We thus have a scenario of the expected temporal changes in community structure, in which the fragment space in occupied by less trees and that the remaining trees has their mean biomass value increased.

We found tree mortality was stable in about 1.4 \%.year ${ }^{-1}$ (est $=0.01 ; p=0.36$ ) (Fig. 3a), while tree recruitment has declined significantly over time from 2.6 to $1.6 \%$.year1 (est $=-0.01 ; p=0.01$ ) (Fig. 3a). Biomass loss decreased significantly over time from 4.5 to $1.6 \%$ year-1 (est=0.92; $p=0.01$ ) (Fig. 3b), while the gain increased, but not significantly (est $=0.01 ; p=0.36$ ) (Fig. $3 b$ ). In this context, the biomass increase is main related to the size increase of remaining trees, since recruitment is not increasing over time. Although we found structural temporal changes, the community species composition was stable, since species richness (est $=-0.01 ; p=0.78$ ) (Fig. $4 a$ ) and the species substitution (est=-0.01; $p=0.65$ ) (Fig. 4b) did not change significantly over time. This result indicates a temporally stable composition in the community, and that temporal changes may had occurred just through punctual changes in the representativity of species already established.

This trend of biomass increment is related to a set of 11 dominant species that are between the 10 first species with high increment between 2005 or 2010 or between 2010 and 2015 (Tab. 1). The first 10 species with the highest increment represent $75.73 \%$ of the total value between 

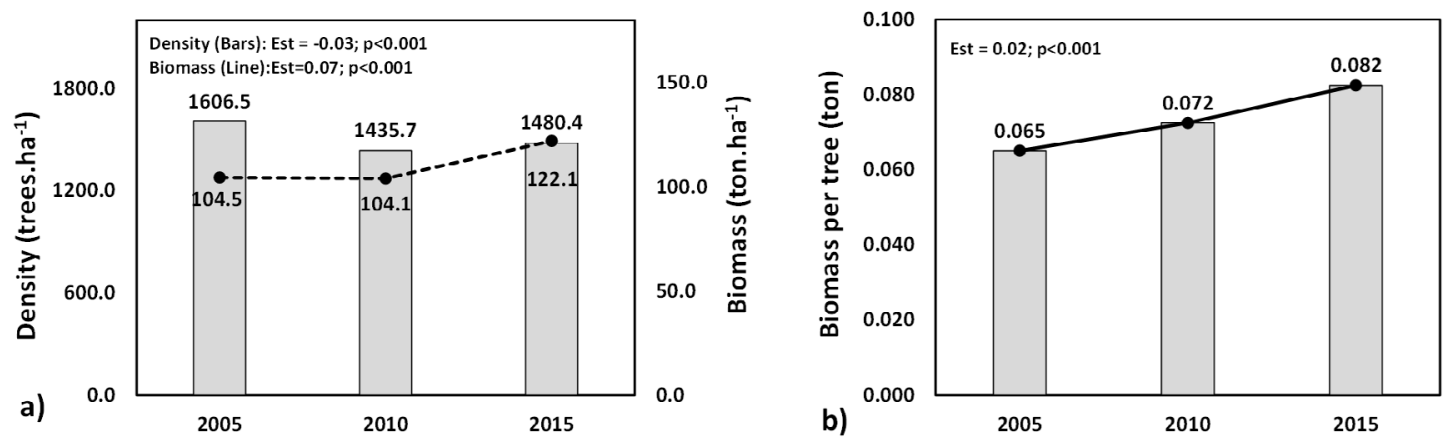

Fig. 2 A: Total of tree density (tree.ha-1) (bars - left axe) and Biomass (ton.ha-1) (black line - right axe) for the three years of measurement; B: Biomass per stem (ton) (bars and black line) for the three years of measurement for the studied seasonally dry tropical forests in Juvenília, Minas Gerais, Brazil. The number on the bars in the fig. a refers to the tree density, while the numbers inside de bars refers to the biomass in each year. The "Est" and " $p$ " refers respectively to values of Estimate and $p$-value in the generalized linear mixed models for each response variable considered.

2005 and 2010 and $70.45 \%$ between 2010 and 2015 (Fig. 5; Tab. 1), while the remaining increment is represented by 82 species in the first interval and by 80 species in the second, demonstrating an uneven growth pattern in biomass between species. Only 1 species present among the 10 in the first interval is not included in the 10 of the second interval, alternating in the 11th position with the species that occupied this position previously. Thus, the forest increment can be represented by a set of 11 species that only change in the increment rank positions.

\section{DISCUSSION}

The seasonally dry tropical forests (SDTF) communities temporal patterns was characterized by floristic stability and significant temporal changes in structure and dynamic. However, the SDTF communities are changing towards more stable stages by the biomass increase and also by the stability of mortality, richness and species substitution over time. These results are probably related to the main SDTF characteristics and to its component species. These forests present ecological processes and evolutionary

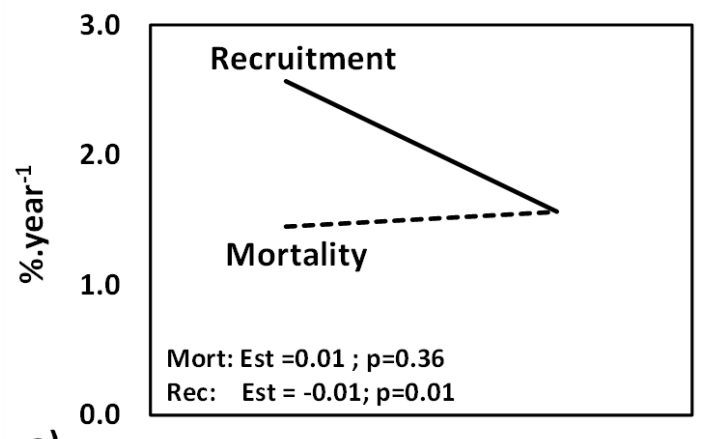

a)

2005 - 2010

$2010-2015$ history directly associated with climatic seasonality, which is

its main restrictive factor (Pennington et al., 2009; DRYFLOR, 2016; Pennington et al., 2018).

The plants in SDTF commonly present adaptations such as stem photosynthesis and reserves tissues that allow the maintenance of growth in initial stages of drought and/or less severe drought, and other adaptations as deciduousness and resprout that ensure the survival in rainfall absence (Dupuy et al., 2012; Santos et al., 2014; Corlett et al., 2016; Tettela-Rangel et al., 2017; Souza et al., 2019). By increasing the individuals survival, theses adaptations may avoid the mortality of species and consequently reduce the occurrence of large biomass losses (Sheil et al., 2000; Maestre et al., 2016; McDowell et al., 2020).

The significant decrease in recruitment may have occurred because of two non-exclusive hypotheses. The first one is related to the dry season intensification, since the germination in these forests is a markedly seasonal process occurring during the rainy season (Morton et al., 2011; Silveira et al., 2016). As result, a shorter rainy season could reduce the several species germination and a longer dry season could lead individuals to death before their establishment, resulting consequently in lower recruitment rates (Silveira et al., 2016). The second one refers to the

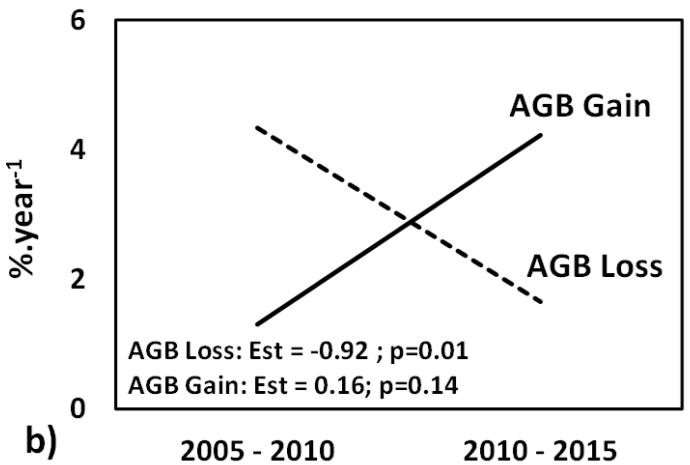

Fig. 3 Annual Taxes of individuals Recruitment and Mortality (\%/year) for the two intervals between years of measurement (a); Annual Taxes of Biomass (AGB) Gain and Loss (\%/year) for the two intervals between years of measurement for the studied seasonally dry tropical forests in Juvenília, Minas Gerais, Brazil (b). The "Est" and "p" refers respectively to values of Estimate and $\mathrm{p}$-value in the generalized linear mixed models for each response variable considered. 

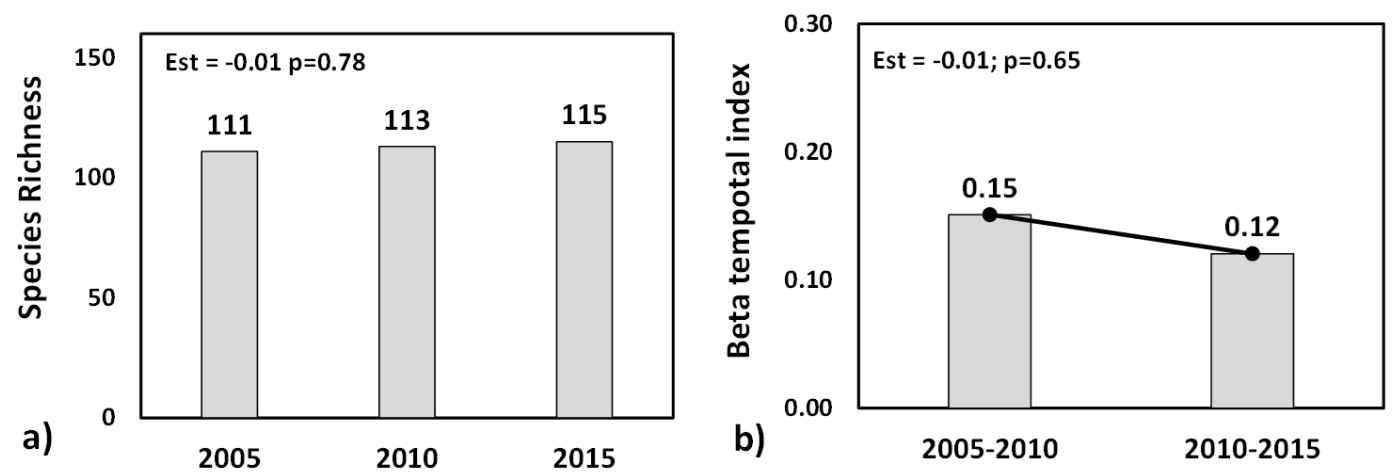

Fig. 4 Total species richness for the three years of measurement (a); Temporal Beta diversity (temporal species substitution) (Bars and black line) for the two intervals between years of measurement for the studied seasonally dry tropical forests in Juvenília, Minas Gerais, Brazil (b). The "Est" and "p" refers respectively to values of Estimate and p-value in the generalized linear mixed models for each response variable considered.

community changes towards temporal stability, which result in biomass increase and consequently in a greater ground coverage and occupation that may reduce the space for the recruitment of new individuals (Lebrija-Trejos et al., 2010; McDowell et al., 2020).

The tree communities biomass is determined by three processes: biomass gain by tree recruitment, biomass growth of surviving trees and loss of biomass due to mortality, and this last tends to be the major determinant of biomass change (Brienen et al., 2015; Rozendaal and Chazdon, 2015; Prado-Júnior et al., 2016; McDowell et al., 2020). Thus, with reduced recruitment and mortality stability, the biomass increase was conditioned by the growth of surviving trees, mainly between dominant species that increase both its total and per individual biomass. This result is demonstrated by the biomass increase related to the increment of few dominant species that account for more than $70 \%$ of the total increment in the two intervals.

This result may be related to the biomass ratio hypothesis proposed by Grime (1998), that predicts that ecosystem processes are driven by the (traits of the) most abundant species in community (van der Sande et al., 2017). In dry forests, these dominant species often are related to conservative characteristics such as high wood density and lower specific leaf area, that commonly is associated to less hydraulic failure and to transpiration reducing (Poorter and Bongers, 2006; Pineda-García et al., 2013; Prado-Junior et al., 2016). By resisting to dry conditions, these species may have their success improved in drought-stressed systems and hence increase their high productivity and biomass storage, and consequently the seasonally dry tropical forests productivity and biomass as a whole (Prado-Junior et al., 2016; van der Sande et al., 2017).

Furthermore, all these high-incremental species are described as SDTF characteristic species (Prado and Gibbs, 1993; Santos et al., 2012; Mogni et al., 2015; DRYFLOR, 2016) with some of them occurring widely in different nuclei, such as Myracrodruon urundeuva Allemão, Anadenanthera colubrina (Vell.) Brenan Tabebuia impetiginosa (Mart. ex DC.) Stand., Commiphora leptophloeos (Mart.) Gillett and Schinopsis brasiliensis Engl. (Prado and Gibbs, 1993; Caetano et al., 2008; Pennington et al., 2009; Mogni et al., 2015; DRYFLOR, 2016). These species can be considered as the most efficient in exploring the available resources, and its wide occurrence can be an indication of ecological plasticity, since the several nuclei present important environmental differences (Pennington et al., 2009; DRYFLOR, 2016; Pennington et al., 2018).

Tab. 1 Most representative species in Biomass increment with their respective values in ton and percentual (\%) in relation to the community as a whole, for the two intervals between forest inventories for the studied Seasonally Dry Tropical Forests in Juvenília, Minas Gerais, Brazil.

\begin{tabular}{|c|c|c|c|c|}
\hline Species & Inc $05-10$ (ton) & $\%$ & Inc $10-15$ (ton) & $\%$ \\
\hline Anadenanthera colubrina (Vell.) Brenan & 4.01 & 14.19 & 2.97 & 12.24 \\
\hline Caesalpinia microphylla Mart. & 0.29 & 1.01 & 1.06 & 4.36 \\
\hline Commiphora leptophloeos (Mart.) Gillett & 0.94 & 3.32 & 1.24 & 5.10 \\
\hline Handroanthus ochraceus (Cham.) Mattos & 2.38 & 8.41 & 1.56 & 6.44 \\
\hline Handroanthus spongiosus (Rizzini) S.Grose & 1.50 & 5.31 & 1.73 & 7.11 \\
\hline Myracrodruon urundeuva Allemão & 5.38 & 19.00 & 3.76 & 15.49 \\
\hline Piptadenia gonoacantha (Mart.) J.F. Macbr. & 1.25 & 4.41 & 1.12 & 4.61 \\
\hline Poincianella pluviosa (DC.) L.P.Queiroz & 1.06 & 3.74 & 1.07 & 4.41 \\
\hline Pseudopiptadenia leptostachya (Benth.) Rauschert & 1.87 & 6.62 & 1.68 & 6.90 \\
\hline Schinopsis brasiliensis Engl. & 1.15 & 4.05 & 0.92 & 3.79 \\
\hline Tabebuia impetiginosa (Mart.ex DC.) Stand. & 1.89 & 6.69 & 0.96 & 3.93 \\
\hline
\end{tabular}


a)

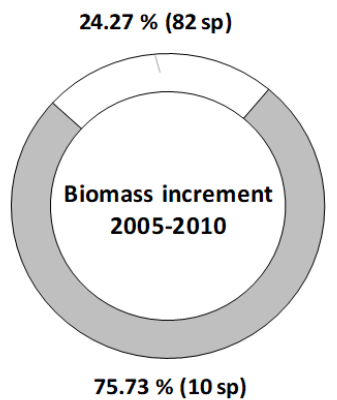

b)

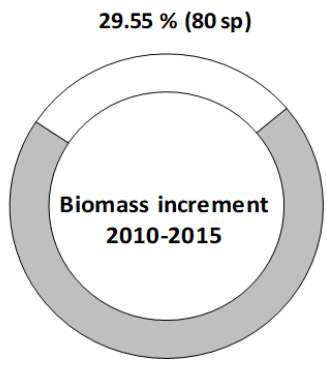

Fig. 5 Representation of the percentage Increment and its related number of species for the first interval (2005-2010) (a) and for the second interval (2010-2015) (b) between measurements for the studied seasonally dry tropical forests in Juvenília, Minas Gerais.
The stability in richness and species composition over time found is related to the mainly restrictive SDTF environmental characteristics, such as the marked climatic seasonality, high temperatures and high light intensity. These harsh conditions select species that present functional characteristics that allow to resist to its conditions (Cadotte and Tucker, 2017; Tetetla-Rangel et al., 2017), and that tend to establish and persist in environments which they are already well adapted (Ackerly, 2003; Donohue et al., 2016; Cadotte and Tucker, 2017; Swenson et al., 2020).

In this context, since species in harsh ecosystems such as the SDTF tend to present a great ecological specialization by habitat, along the forest dynamic the dead individuals tend to be replaced by members of their own species (Connel and Slatyer, 1997, Swenson et al., 2020). This process is one of the most important diversity maintenance mechanisms (Connell and Slatyer, 1977; Chesson et al. 2018), since they improve the communities local diversity (alpha), endemism and beta diversity (DRYFLOR, 2016). Besides this, the stability in species composition may also be associated with the sites good state of preservation, since disturbances is an important driver of changes in natural communities (Cavalcanti et al., 2009; Swanson et al., 2011; McDowell et al., 2020).

The SDTF were historically neglected by the scientific community, with still incipient knowledge about its ecological patterns (Allen et al., 2017; Sunderland et al., 2015). For example, while for Rainforest studies with more than 20 years are common (Lewis et al., 2009; Phillips and Lewis, 2014; Esquivel-Muelbert et al., 2017; Sullivan et al., 2020), the present study represents with 10 years of monitoring one of the largest periods already registered for Seasonally Dry Tropical Forest. The construction and improvement of this knowledge is urgent considering the importance of these forests for biodiversity and ecosystem services provision, and to their conservation current state by the intense land conversion and the low insertion in Conservation Units (Sunderland et al., 2015; DRYFLOR, 2016; Maestre et al., 2016).

\section{CONCLUSION}

The Seasonally Dry Tropical Forests temporal patterns are associated to different trends in relation to other vegetation types by presenting floristic stability and changes to more stable stages, with crescent increment of a set of important SDTF species. These responses are driven by the main ecological environmental factors present in this vegetation type, such as the climatic seasonality, that is extremely important also in contexts of environmental changes in macro and local scale, such as from climate changes and logging.

\section{ACKNOWLEDGEMENT}

To Federal University of Lavras, Foundation for the Support to the Researches in Minas Gerais (FAPEMIG), Brazilian National Council for Scientific and Technological Development (CNPq) and to Coordination for the Improvement of Higher Education Personnel (CAPES) for all the support.

\section{AUTHORSHIP CONTRIBUTION}

\author{
Project Idea: CRS, RMS
}

Funding: CRS, RMS

Database: CRS, ABMS, VAM, PAC, GGPP, NCAF, PFS, POG, RMS

Processing: JDM, PFS, CRS, ABMS, VAM, RMS

Analysis: CRS, VAM RMS

Writing: PFS, CRS, ABMS, VAM, GGPP, NCAF, PAC, RMS Review: CRS, ABMS, VAM, GGPP, NCAF, PAC, PFS, POG,

RMS

\section{REFERENCES}

ACKERLY, D.D. Community assembly, niche conservatism, and adaptive evolution in changing environments. International Journal of Plant Sciences, v. 164, n. S3, p.165-184, 2011.

ALBUQUERQUE, U.P.; ARAÚJO, E.L.; EL-DEIR, A.C.A.; LIMA, A.L.A.; SOUTO, A.; BEZERRA, B.M.; FERRAZ, E.M.N.; FREIRE, E.M.X.; SAMPAIO, E.V.S.B.; LAS-CASAS, FM.G: MOURA, G.J.B: PEREIRA G.A: MELO, JG: RAMOS, M.A: RODAL, M.J.N. SCHIEL, N.; LYRA-NEVES, R.M.; ALVES, R.R.N.; AZEVEDO-JÚNIOR S.M.; TELINO JÚNIOR, W.R.; SEVERI, W. Caatinga revisited: ecology and conservation of an important seasonal dry forest. The Scientific World Journal, v.2012, p. 205182, 2012.

ALLEN, K.; DUPUY, J.M.; GEI, M.G.; HULSHOF, C.; MEDVIGY, D.; PIZANO, C.; SALGADO-NEGRET, B.; SMITH, C.M.; TRIERWEILER, A.; BLOEM, S.J.V. Will seasonally dry tropical forests be sensitive or resistant to future changes in rainfall regimes? Environmental Research Letters, v. 12, n. 2, p. 023001, 2017.

ANGIOSPERM PHYLOGENY GROUP. An update of the Angiosperm Phylogeny Group classification for the orders and families of flowering plants: APG IV. Botanical Journal of the Linnean Society, v.181, p.1-20, 2016

BRIENEN, R.J.W.; et al. Long-term decline of the Amazon carbon sink. Nature, v.519, p.344-348, 2015. 
BELLO, F., VALENCIA, E., WARD, D., HALLETT, L. Why we still need permanent plots for vegetation science. Journal of Vegetation Science, v.31, 2020.

CADOTTE, M.W.; TUCKER, C.M. Should environmental filtering be abandoned?. Trends in ecology \& evolution, v. 32, n. 6, p. 429-437, 2017.

CAETANO, S.; PRADO, D.; PENNINGTON, R.T.; BECK, S.; OLIVEIRA-FILHO A.T.; SPICHIGER, R.; NACIRI, Y. The history of Seasonally Dry Tropical Forests in eastern South America: Inferences from the genetic structure of the tree Astronium urundeuva (Anacardiaceae). Molecular Ecology, v.17, n.13, p. 3147-3159, 2008

CHAVE, J.; RÉJOU-MÉCHAIN, M.; BÚRQUEZ, A.; CHIDUMAYO, E COLGAN,' M.S.; DELITTI, W.B.; DU'QUE, A.; EID, T.; FEARNSIDE, P.M.; GOODMAN, R.C.; HENRY, M.; MARTÍNEZ-YRIIZAR, A.; MUGASHA W.A: MULLER-LÁNDAU, H.C: MENCUCCINI, M: NELLSON, B.W. NGÖMANDA, A.; NOGUEIRA, E.M.; ORTIZ-MALÁVASSI, E.; PÉLISSIER, R. PLOTON, P.; RYAN, C.M.; SALDARRIAGA, J.G.; VIEILLEDENTT, G. Improved allometric models to estimate the aboveground biomass of tropica trees. Global change biology, v.20, n.10, p. 3177-3190, 2014.

CHESSON, P. Updates on mechanisms of maintenance of species diversity Journal of ecology, v. 106, n.5, p. 1773-1794, 2018

CONNELL, J.H.; SLATYER, R.O. Mechanisms of succession in natura communities and their role in community stability and organization. The American Naturalist, v. 111, n. 982, p.1119-1144, 1977

CORLETT, R.T. The impacts of droughts in tropical forests. Trends in plant science, v.21, n.7, p. 584-593, 2016.

DRYFLOR. Plant diversity patterns in neotropical dry forests and their conservation implications. Science, v.353, n. 6306, p.1383-1387, 2016.

DONOHUE, I.; HILLEBRAND, H.; MONTOYA, J.M.; PETCHEY, O.L.; PIMM, S.L: FOWLER M.S: HEALY K: JACKSON A.L: LURGI, M.; MCCLEAN, D. O'CONNOR, N.E.; O'GORMAN, E.J.; YANG, Q. Navigating the complexity of ecological stability. Ecology Letters, v. 19, p. 1172-1185, 2016

DUPUY JM: HERNÁNDEZ-STEFANONI 」) HERNÁNDEZ-JUÁREZ RA TETETLA-RANGEL, E.; LÓPEZ-MARTÍNEZ, J.O.; LEYEQUIÉN-ABARCA, E.; TUNDZUL, F.J.; MAY-PAT, F. Patterns and correlates of tropical dry forest structure and composition in a highly replicated chronosequence in Yucatan, Mexico. Biotropica, v.44, n.2, p.151-162, 2012.

ESQUIVEL-MUELBERT, A.; et al. Compositional response of Amazon forests to climate change. Global Change Biology, v. 25, n.1, p. 39-56, 2017

FEELEY, K.J: BRAVO-AVILA, C.FADRIQUE, B.: PEREZ, T.M: ZULETA, D. Climatedriven changes in the composition of New World plant communities. Nature Climate Change, v. 2020 , p. 1-6, 2020

GRIME, J.P. Benefits of plant diversity to ecosystems: immediate, filter and founder effects. Journal of Ecology, v.86, p.902-910, 1998.

LEBRIJA-TREJOS, E.; PÉREZ-GARCÍA， E.A.; MEAVE， J.A.; BONGERS, F. POORTER, L. Functional traits and environmental filtering drive community assembly in a species-rich tropical system. Ecology, v.91, n.2, p.386-398, 2010

LEHMAN, C.L.; TILMAN, D. Biodiversity, stability, and productivity in competitive communities. The American Naturalist, v.156, n.5, p.534-552, 2000

LEWIS, S.L.; LLOYD, J.; SITCH, S.; MITCHARD, E.T.A.; LAURANCE, W.F. Changing ecology of tropical forests: evidence and drivers. Annual Review of Ecology, Evolution, and Systematics, v.40, p.529-549, 2009

MAESTRE, F.T.; ELDRIDGE, D.J.; SOLIVERES, S.; KÉFI, S.; DELGADO-BAQUERIZO M: BOWKER, M.A: GARCIA-PALACIOS, P: GAITAN, J: GALLARDO, A LÁZARO, R.; BERDUGO, M. Structure and functioning of dryland ecosystems in a changing world. Annual review of ecology, evolution, and systematics, v. 47, p.2015-237, 2016

MAIA VA : SOUZA C R : AGUIAR-CAMPOS, N F FAGUNDES, NCA : SANTOS, A.B.M.; PAULA, G.G.P.; SANTOS, P.F.; SILVA, W.B.; MENINO, G.C.O.; SANTOS, R.M. Interactions between climate and soil shape tree community assembly and above-ground woody biomass of tropical dry forests. Forest Ecology and Management, v. 474, p.118348, 2020.

MCDOWELL, N.G.; ALLEN, C.D.; ANDERSON-TEIXEIRA, K.; AUKEMA, B.H.; BOND-LAMBERTY, B.; CHINI, L.; CLARK, J.S.; DIETZE, M.; GROSSIORD C.; HANBURY-BROWN, A.; HURTT, G.C.; JACKSON R.B.; JOHNSON, D.J.; KUEPPERS, L.; LICHSTEIN, J.W.; OGLE, K.; POULTER, B.; PUGH, T.A.M.; SEIDL, R. TURNER, MG.: URIARTE, M. WALKER A.P. HURTT, G.C. Pervasive shifts in forest dynamics in a changing world. Science, v.368, n.6494, p.eaaz9463, 2020

MEYER, PB : OLIVEIRA-FILHO, A.T: BOTEZELLI, L: FONTES, M.A.L: GARCIA P.O.; SANTOS, R.M. Dinâmica estrutural em um fragmento de Floresta Estacional Semideciduifólia em Lavras, MG, Brasil. Revista Cerne, v.21, n.2, p.259-265, 2015.
MOGNI, V.Y.; OAKLEY, L.J.; PRADO, D.E. The distribution of woody legumes in neotropical dry forests: the Pleistocene Arc Theory 20 years on. Edinburgh Journal of Botany, v.72, n.1, p.35-60, 2015

MORTON, S.R.; SMITH, D.S.; DICKMAN, C.R.; DUNKERLEY, D.L.; FRIEDEL, M.H.: MCALLISTER, R.R.J.; REID, J.R.W.; ROSHIER, D.A.; SMITH, M.A WALSH, F.J: WARDLE, G.M. WATSON, I.W. WESTOBY, M. A fresh ramework for the ecology of arid Australia. Journal of Arid Environments, v.75, n.4, p.313-329, 2011.

NIU, S: LUO, Y: LI, D: CAO S: XIA, J: LI, J: SMITH, M.D. Plant growth and mortality under climatic extremes: an overview. Environmental and Experimental Botany, v.98, p.13-19, 2014.

PHILLIPS, O.L.; LEWIS, S.L. Evaluating the tropical forest carbon sink. Global Change Biology, v.20, n.7, p.2039-2041, 2014

PINEDA-GARCÍA, F.; PAZ, H.; MEINZER, F.C. Drought resistance in early and late secondary successional species from a tropical dry forest: the interplay between xylem resistance to embolism, sapwood water storage and leaf shedding. Plant, Cell and Environment, v.36, p.405-418, 2013

PENNINGTON, R.T.; LAVIN, M.; OLIVEIRA-FILHO, A. Woody plant diversity, evolution, and ecology in the tropics: perspectives from seasonally dry tropical forests. Annual Review of Ecology, Evolution, and Systematics, v.40, p.437-457, 2009

PENNINGTON, R.T: LEHMANN, C.E.R: ROWLAND, L.M. Tropical savannas and dry forests. Current Biology, v. 28, n. 9, p. R541-R545, 2018.

PRADO, D.E.; GIBBS, P.E. Patterns of species distributions in the dry seasonal forests of South America. Annals of the Missouri Botanical Garden, v.80, n.4 p. $902-927,1993$

PRADO-JUNIOR, J.A.; SCHIAVINI, I.; VALE, V.S.; ARANTES, C.S.; VAN DER SANDE, M.T.; LOHBECK, M.; POORTER, L. Conservative species drive biomass productivity in tropical dry forests. Journal of Ecology, v.104, n.3, p.817-827, 2016.

POORTER, L.; BONGERS, F. Leaf traits are good predictors of plant performance across 53 rain forest species. Ecology, v.87, p.1733-1743, 2006.

REIS, G.H.; TERRA, M.D.C.N.S.; TNG, D.Y.P.; APAGAUA, D.M.G.; COELHO, P.A.; SANTOS, R.M.; NUNES, Y.R.F. Temporal vegetation changes in a seasonally dry tropical forest enclave in an ecotonal region between savanna and semiarid zones of Brazil. Australian journal of botany, v.65, n.1, p.85-93, 2017.

RÉJOU-MÉCHAIN, M.; TANGUY, A.; PIPONIOT, C.; CHAVE, J.; HÉRAULT, B. biomass: An r package for estimating above-ground biomass and its uncertainty in tropical forests. Methods in Ecology and Evolution, v.8, n.9, p.1163-1167, 2017.

ROITMAN, I.; VANCLAY, J.K.; HAY, J.D.; FELFILI, J.M. Dynamic equilibrium and decelerating growth of a seasonal Neotropical gallery forest in the Brazilian savanna. Journal of Tropical Ecology, v.32, n.3, p.193-200, 2016

ROZENDAAL, D.M.A.; CHAZDON, R.L. Demographic drivers of tree biomass change during secondary succession in northeastern Costa Rica. Ecological Applications, v.25, p.506-516, 2015

SANTOS, A.B.M.; CARVALHO, W.A.C.; MOREL, J.D.; SOUZA, C.R.; SANTOS, R.M.; SILVA, T.M.C.; FIGUEIREDO, M.A.P.; SILVA, K.G. Variations in precipitation and the equilibrium dynamics of a tropical forest tree community in SouthEastern Brazil. Journal of Tropical Forest Science, v.30, n.4, p. 597-605, 2018

SANTOS, M.G.; OLIVEIRA, M.T.; FIGUEIREDO, K.V.; FALCÃO, H.M.; ARRUDA E.C.P. ALMEIDA-CORTEZ, J. SAMPAIO, E.V.S.B.: OMETTO, J.P.H.B.: MENEZES, R.S.C. OLIVEIRA AFM. POMPELU MF. ANTONINO A.C. Caatinga the Brazilian dry tropical forest: can it tolerate climate changes? Theoretical and Experimental Plant Physiology v.26, p.83-99, 2014.

SANTOS, R.M: OLIVEIRA-FILHO, A.T: EISENLOHR, P.V: QUEIROZ L P. CARDOSO, D.B.O.D.; RODAL, M.J.N. Identity and relationships of the Arboreal Caatinga among other floristic units of seasonally dry tropical forests (SDTFs) of north-eastern and Central Brazil. Ecology and Evolution, v.2, p.409-428, 2012

SHEIL, D.; JENNINGS, S.; SAVILL, P. Long-term permanent plot observations of vegetation dynamics in Budongo, a Ugandan rain forest. Journal of Tropical Ecology, v.16, n.6, p. 785-800, 2000.

SILVEIRA, A.P.; MARTINS, F.R.; ARAÚJO, F.S. Life history and population dynamics of a tree species in tropical semi-arid climate: A case study with Cordia oncocalyx. Austral Ecology v.42, n.3, p.329-340, 2016

SOUZA C R - MOREL, JD: SANTOS, A B M. SILVA, WB B MAIA, V. A : COELHO, P.A.; REZENDE, V.L.; SANTOS, R. M. Small-scale edaphic heterogeneity as a floristic-structural complexity driver in Seasonally Dry Tropical Forests tree communities. Journal of Forestry Research, v.2019, p.1-11, 2019.

SULLIVAN, M.J; et al. Long-term thermal sensitivity of Earth's tropical forests. Science, v.368, n.6493, p. 869-874, 2020. 
SUNDERLAND, T.C.H.; APGAUA, D.; BALDAUF, C.; BLACKIE, R.; COLFER, C.J.P.; CUNNINGHAM, A.B.; DEXTER, K.; DJOUDI, H.; GAUTIER, D.; GUMBO D.; ICKOWITZ, A.; KASSA, H.; PARTHASARATHY, N.; PENNINGTON, R.T. PAUMGARTEN, F; PULLA, S.; SOLA, P.; TNG, D.; WAEBER, P.; WILMÉ, L. Global dry forests: a prologue. International Forestry Review v.17, n.S2, p.1-9, 2015.

SWENSON, N.G.; HULSHOF, C.M.; KATABUCHI, M.; ENQUIST, B.J. Long-term shifts in the functional composition and diversity of a tropical dry forest: a 30-yr study. Ecological Monographs, v.90, n.3, p.e01408, 2020

SWANSON, M.E.; FRANKLIN, J.F.; BESCHTA, R.L.; CRISAFULLI, C.M.; DELLASALA, D.A.; HUTTO, R.L.; LINDENMAYER, D.B. The forgotten stage of forest succession: Early-successional ecosystems on forest sites. Frontiers in Ecology and the Environment, v.9, n.2, p.117-125, 2011
TETETLA-RANGEL, E.; DUPUY, J.M.; HERNÁNDEZ-STEFANONI, J.L.; HOEKSTRA, P.H. Patterns and correlates of plant diversity differ between common and rare species in a neotropical dry forest. Biodiversity and Conservation, v.26, n.7, p. 1705-1721, 2017.

TOLEDO M.: POORTER, L.: PEÑA-CLAROS, M: ALARCÓN, A: BALCÁZAR, J.; LEAÑO, C.; LICONA, J.C.; LLANQUE, O.; VROOMANS, V.; ZUIDEMA, P.; BONGERS, F. Climate is a stronger driver of tree and forest growth rates than soil and disturbance. Journal of Ecology, v.99, n.1, p. 254-264, 2011

VAN DER SANDE, M.T.; POORTER, L.; KOOISTRA, L.; BALVANERA, P. THONICKE, K.; THOMPSON, J.; ARETS, E.J.M.M.; GARCIA ALANIZ, N.; JONES L.; MORA, F.; MWAMPAMBA, T.H.; PARR, T.; PENA-CLAROS, M. Biodiversity in species, traits, and structure determines carbon stocks and uptake in tropical forests. Biotropica, v.49, n.5, p.593-603, 2017. 